\section{RESENHA}

Recebido em: 13/08/2016

Aceito em:

10/11/2016

\title{
A Biblioteconomia de David Lankes
}

LANKES, R. David. The New Librarianship field guide. Cambridge, MA: MIT Press, 2016. 240 p. ISBN 9780262529082.

Jorge Moisés Kroll do PRADO (jorge.exlibris@gmail.com)*

* Bibliotecário do SENAC/SC. Doutorando em Ciência da Informação pela Universidade Federal de Santa Catarina

A Biblioteconomia tem oferecido cada vez mais reflexões pautadas numa sociedade conectada, em rede, com diferentes necessidades informacionais. Por conta disso, torna-se inevitável pensar o trabalho cotidiano do bibliotecário frente a esta demanda, tendo de desenvolver ou adquirir novas competências e habilidades e como se configura a biblioteca podendo ter no seu acervo mais do que somente os livros. Um dos autores que está contribuindo neste quesito é o professor norte-americano Richard David Lankes, ou mais conhecido como David Lankes, que em junho de 2016 lançou a obra The New Librarianship Field Guide, editada pela MIT Press.

David Lankes é bacharel em Estudos Especiais em Artes, com foco em Design de Multimídia, mestre em Telecomunicações e doutor em Transferência da Informação; toda a formação acadêmica pela Universidade de Syracuse, em Nova York. Nessa instituição, enquanto professor a partir de 2009, foi responsável pelo desenvolvimento do Mestrado em Biblioteconomia e Ciência da Informação, programa onde iniciou suas reflexões acerca da Nova Biblioteconomia com uma linha de pesquisa direcionada a ela. Atualmente é diretor da School of Library \& Information Science na Universidade da Carolina do Sul, nos Estados Unidos.

Quanto às suas publicações, Lankes é autor e coautor de 38 livros, mais de 40 capítulos de livros, além de artigos de periódicos. É com as últimas três obras, entretanto, que a visibilidade do termo que cunhou, Nova Biblioteconomia, cresceu e ultrapassou as fronteiras de seu país. Em 2011, Lankes publicou The Atlas of New Librarianship, uma obra técnica e de referência que apresenta uma nova formatação profissional do bibliotecário. No ano seguinte, como uma espécie de interpretação do Atlas, é publicado Expect More: demanding better libraries for today's complex world, que numa linguagem muito mais próxima e intimista do leitor, traz exemplos de atuação de bibliotecários que atuam conforme esta Nova Biblioteconomia apresentada no livro anterior. É com Expect More que a visibilidade do conceito cresce, uma vez que a estratégia editorial do autor foi a publicação em acesso aberto, em diferentes formatos de leitura (inclusive em áudio) ${ }^{1}$.

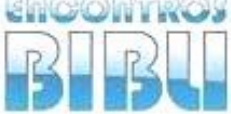

v. 22, n. $48,2017$. p. $100-102$

ISSN 1518-2924

1 Expect More foi traduzido por Jorge do Prado e lançado também em acesso aberto, durante a $26^{\mathrm{a}}$ edição do Congresso Brasileiro de Biblioteconomia e Documentação, realizado em julho de 2015 em São Paulo. A partir do evento, quinzenalmente era publicado um capítulo traduzido num formato que propiciasse a discussão, sendo aberto para que os leitores interagissem com o texto (destacar frases, realizar questionamentos, engajar-se com outros leitores). 0 livro continua acessível para leitura e interação no site do autor: http://davidlankes.org/?page id=8274 (Acesso em: 08 ago. 2016). 
Como uma espécie de terceiro volume, Lankes traz em The New Librarianship Field Guide (que aqui chamarei como The Field Guide) orientações de como colocar em prática a técnica apresentada no Atlas, tendo como benchmarking os exemplos trazidos em Expect More. Os três livros não foram concebidos em formato de série, mas pode-se perceber um fio condutor entre os textos, mas ainda assim tênue, o que acaba possibilitando também a leitura individual das obras.

O livro está dividido em quatro grandes partes: "Librarianship: full stop", "Librarians", "Libraries" e "Excursus: from mission to missionary". A linguagem utilizada é a mesma do livro anterior, bastante intimista, num tom conversacional, em primeira pessoa e sempre resgatando exemplos reais de bibliotecários que atuam conforme este novo conceito de "Nova Biblioteconomia" proposto pelo autor.

Na primeira parte, "Librarianship: full stop", Lankes traz um texto que utilizou em uma de suas aulas iniciais no curso de Biblioteconomia que apresenta o contexto egípcio, mais especificamente durante as manifestações da Primavera Árabe. Seu olhar se detém para a famosa Biblioteca de Alexandria, que mesmo durante os protestos que tiraram do poder o Presidente Mubarak, não teve uma janela sequer quebrada de sua estrutura. Demonstra-se assim a importância da biblioteca para a comunidade, o valor que ela tinha para o Egito em aspectos culturais, históricos, sociais e inclusive econômicos.

Ainda nesta parte introdutória, o autor apresenta os significados possíveis para "radical", um adjetivo que ele associa à transformação que pode ser proporcionada por bibliotecários e pelo espaço da biblioteca. Este termo virá acompanhado muitas vezes no decorrer do livro acompanhado do aspecto de construção do conhecimento da comunidade, em que a ocupação do bibliotecário não pode ser passiva, de espera, mas sim mais atuante de maneira ativa e prospectiva.

Em "Librarians", a segunda parte do livro, o foco de Lankes se dá em oito capítulos que discutem qual a missão dos bibliotecários, seus valores e os significados de facilitação de criação de conhecimento pela comunidade. Ao falar de missão, o autor apresenta que muitas delas são construídas, desenvolvidas e trabalhadas ao redor do acervo, ao invés da comunidade, que para ele é o ponto com o qual o bibliotecário deveria mais se preocupar. Quanto a valores, baseado no Currículo de Salzburg2, são evidenciadas algumas características para o trabalho do bibliotecário numa era de cultura da participação, como o engajamento social transformador, as tecnologias, a gestão de ativos e as habilidades multiculturais. Já a discussão sobre a maneira de se facilitar a criação de conhecimento da comunidade está muito ligada com os valores do bibliotecário apresentados ainda nesta parte do livro. A preocupação que se deve ter o profissional com as diferentes necessidades informacionais, sobre o desenvolvimento de um acervo eficiente, quais ferramentas propiciam e aceleram esta criação.

A terceira parte do livro, "Libraries", dedica-se ao espaço de atuação do bibliotecário conforme as características apontadas nos capítulos anteriores. 0 objetivo é apontar que a biblioteca é desenvolvida pela comunidade, administrada pelo bibliotecário e dedicada para a criação de conhecimento.

Lankes remete à quinta lei da Biblioteconomia de Ranganathan, de que "a biblioteca é um organismo em crescimento", para mostrar o processo evolutivo deste espaço ao longo do tempo. Um olhar bastante atento é dado ao desenvolvimento de produtos e de serviços, bem como da construção de acervos e espaços coletivos de aprendizagem (como os makerspaces). São nove capítulos que compõem esta terceira parte, sendo três deles abordando separadamente as bibliotecas universitárias, as escolares e as públicas; tornando assim o livro ainda mais completo, atendendo aos principais contextos profissionais atuais.

É na última parte, entretanto, que The Field Guide se configura realmente como um guia. Todas os aspectos apresentados nos capítulos anteriores são resgatados brevemente neste momento do livro para atentar ao modus operandi, ao "como fazer". David Lankes traz um conjunto de ferramentas e boas práticas para a Nova Biblioteconomia, além de trazer uma seção de "Perguntas Frequentes" respondidas reflexivamente. Há sempre um convite ao leitor bibliotecário para que pense como está a sua atuação, como a sua biblioteca está atendendo às necessidades e anseios informacionais da sua comunidade. Para

20 Currículo de Salzburg foi criado em 2011, na Áustria, por profissionais de diferentes países que foram convidados a construir um documento que trouxesse quais as principais competências e habilidades do bibliotecário numa cultura da participação. O Currículo pode ser lido na íntegra em:

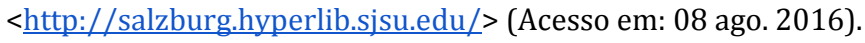


complementar, uma vasta lista de leituras adicionais são sugeridas para cada capítulo, tanto de textos mais acadêmicos como de relatos de bibliotecários atuantes na perspectiva debatida ao longo do texto.

The New Librarianship field guide é mais um livro de David Lankes simples de ser lido, pela linguagem adotada, pelo convite à conversa com o leitor, mas bastante questionador e desafiador para o que se propõe. A Nova Biblioteconomia é um conceito recente, que resume algumas práticas e pensamentos, ambos inovadores, de bibliotecários que merece ser debatido nos âmbitos profissional e acadêmico.

Editores do artigo: Adilson Luiz Pinto, Rafaela Paula Schmitz e Enrique Muriel-Torrado 